\title{
Humor golpista: memes sobre Dilma Rousseff durante o "impeachment"
}

\author{
Georg Wink ${ }^{*}$
}

\section{Introdução}

No Brasil de hoje, "memes de internet" são um formato onipresente no âmbito da comunicação pelas mídias sociais. Entendem-se como tais hashtags, textosfrase, foto-legendas, tirinhas, vídeos, sempre produzidos digitalmente por internautas que recorrem a ferramentas disponíveis na rede (4chan, 9.gag.com, entre outros) e repassados, muitas vezes de forma alterada, por meios eletrônicos, tais como Twitter, Facebook ou Instagram. Não é surpreendente que os memes logo tenham passado a serem usados também amplamente para comentar humoristicamente questões da política do dia a dia, seja para criticar, afirmar ou apenas para "zoar". No Brasil, o fenômeno se manifestou, pela primeira vez, durante o assim chamado "mensalão do PT" e logo depois, maciçamente, nas eleições de 2014, que por isto foram batizadas de "eleições dos memes" (ChagAs et al., 2015, p. 1).

O próprio conceito de "meme de internet", ainda usado para qualquer peça de informação que se espalha rapidamente e extensamente ("viraliza") na internet, surgiu já no final dos anos 1990, na própria rede. ${ }^{1}$ Logo depois, o novo fenômeno atraiu o interesse, ainda escassamente, de escritos acadêmicos. Entretanto, a incipiente produção acadêmica internacional sobre memes de internet ainda não chegou a construir uma base teórica e uma metodologia contundentes. Quase todos estes trabalhos pioneiros têm em comum o fato de tomarem como ponto de partida a proposta que deu origem ao termo "meme", cunhado pelo biólogo Richard Dawkins, em seu livro The selfish gene, publicado em 1976. Neste, Dawkins compara a evolução cultural com a evolução genética e elabora uma analogia entre gene e o neologismo "meme" para sugerir que o último seria equivalente a um gene da cultura. A partir desta hipótese, propõe que o meme, funcionando como unidade de replicação cultural, se perpetuaria através de seus replicadores, as pessoas, por meio de um processo de imitação (DAwkins, 1976, p. 214).

\footnotetext{
Professor associado de Estudos Brasileiros na Universidade de Copenhague. E-mail: georg.wink@hum.ku.dk

1 Recorrem a este termo Joshua Schachter, em seu site "Memepool" em 1999, e Jonah Peretti, em seu site "Contegious Media” em 2000 (HorTA, 2015, p. 13-14).
} 
A proposta de Dawkins desencadeou toda uma linha de pensamento com embasamento na mesma analogia (CASTAÑo DíAZ, 2013). Embora uma ideia sedutora, parece-me uma tendência periclitante por vários motivos. Primeiro, porque foram levantadas objeções severas em relação à coerência desta abordagem (ver, por exemplo, o resumo de BüLOW, 2013), que ainda não foram devidamente esclarecidas. Segundo, porque esta linhagem de pensamento apresenta mais um caso típico de interpretação de um fenômeno social (a cibercultura) e, portanto, em princípio da competência das ciências sociais e humanas, pelas ciências da natureza (especialmente a biologia). Mesmo que o estudo interdisciplinar possa contribuir para a iluminação de pontos cegos na ciência e mesmo que a conexão entre as duas áreas possa ser entendida apenas metaforicamente, há o risco de se estabelecer, de forma acrítica, modelos biológicos incompatíveis com a complexidade social, com consequências limitadoras em termos de produção de conhecimento e um grande potencial manipulativo ideológico, tal como mostrou o caso já clássico da difusão do darwinismo social. Terceiro, porque as incursões no campo das humanidades, empreendidas por Dawkins e seus seguidores, representam uma perspectiva datada sobre "cultura". Esta perspectiva sofre da mesma limitação conceitual e teórica que, por exemplo, a visão essencialista de cultura, tal como defendida, ainda hoje, pelo mais famoso representante da vertente culturalista da comunicação intercultural, Geert Hofstede, que insiste em entender cultura em analogia a organismos naturais, células e DNA biológicos (HoFsTEDE et al., 2010, p. 26). Em ambos os casos, não se considera que "cultura" seja algo construído, e não simplesmente herdado; que expressões culturais são baseadas em escolhas estratégicas e sempre contextualizadas, e não apenas naturais e iminentes; e que cultura é híbrida e nunca estática.

Portanto, pensar o fenômeno dos "memes" a partir de Dawkins, simplesmente pela autoria do termo, seria equivalente a ignorar todo o conhecimento que tem sido produzido pelos estudos culturais (especialmente nas suas vertentes póscoloniais e pós-modernas) desde o cultural turn dos anos 1980. O risco de se retroceder epistemologicamente pela confortável acolhida desta abordagem superada não é compensado pela vantagem oportuna de usufruir dos modelos providenciados, ainda que estes, sem dúvida, sejam de fácil aplicação ao fenômeno dos memes de internet. O problema é que pela insuficiência da base teórica, datada e limitada disciplinarmente, estes modelos pouco contribuem para além de sua função descritiva. Por exemplo, seguindo a linha de Dawkins, Blackmore (1999) aponta, em sua proposta de um algoritmo evolucionário cultural, três características essenciais que garantiriam a sobrevivência de memes culturais, mais uma vez em analogia à biologia: a capacidade do meme de permanecer no tempo (longevidade); a capacidade de gerar cópias (fecundidade); e a capacidade de gerar cópias semelhantes ao original, permitindo o seu reconhecimento (fidelidade). Sem considerar nenhuma das teorias mais centrais que os estudos culturais têm produzido sobre a circulação e apropriação de artefatos culturais: por processos de mímica e diferença (no 
sentido pós-estruturalista), intertextualidade, polifonia e recepção, para apenas citar alguns; o modelo descritivo de Blackmore é de uma trivialidade aterradora.

Logo, podemos concluir que será imprescindível e urgente para a investigação apropriada do novo fenômeno dos memes de internet criar um novo marco teórico, emancipado do determinismo sociobiológico e em concordância com o estado da arte interdisciplinar. Por enquanto, no Brasil, são mais visíveis os avanços metodológicos para quantificar sua presença e rastrear a dinâmica de sua disseminação, como realizados pela Diretoria de Análise de Políticas Públicas (DAPP) da Fundação Getulio Vargas e pelo Laboratório de Imagem e Cibercultura (LABIC) da Universidade Federal do Espírito Santo (Freitas, 2016; Malini, 2016; SouzA; Goveia, 2016; entre outros). Tal empreendimento, pela quantidade de dados e pela temporalidade de sua presença, termina sendo uma tarefa que exige ferramentas técnicas extremamente sofisticadas (BAUCKHAGE, 2011), além do desenvolvimento de uma nova base conceitual (WIGGINS; BowERS, 2014; SEgEV et al., 2015). Entretanto, apenas uma análise que suplemente esta dimensão quantitativa dos processos de disseminação com uma investigação qualitativa, em relação aos conteúdos e às formas, poderia responder as perguntas mais relevantes que dizem respeito ao significado social e político dos memes (por exemplo, o complexo de perguntas "como funciona o processo pelo qual memes com quais caraterísticas desenvolvem qual impacto político em relação a qual grupo social?”). Por enquanto, respostas a este tipo de pergunta ainda têm caráter meramente especulativo (CHAGAS, 2015; PeNNEY, 2016). A investigação do lado qualitativo está mais avançada, por permitir um delineamento de pesquisa como estudo de caso. Existem alguns trabalhos pioneiros que chegaram a produzir resultados valiosos, por exemplo, memes como uma nova expressão da cultura digital com potencial democrático (SHIFMAN, 2014; entre outras publicações e copublicações da mesma autora); sobre a interação social por meio de memes (RECUERO, 2006; BARRETO, 2015); memes e a sua comunicação como linguagem da internet (HORTA, 2015); e o discurso (humorístico) dos memes (KNOBEL; LANKShear, 2007; Milner, 2012, 2013; TAY, 2014; Chagas, 2016).

\section{Considerações teóricas e metodológicas}

Em minha contribuição, examinando memes produzidos na ocasião do assim chamado "impeachment" contra Dilma Rousseff e visando-a pessoalmente, sigo a esteira desses últimos trabalhos que seguem uma abordagem de análise de conteúdos e formas. Em decorrência das dificuldades acima descritas, que se manifestam na investigação de memes de internet, é mister esclarecer a metodologia. Primeiro, entendo minha investigação como meramente exploratória e não exaustiva, limitada a um estudo preliminar de caso, uma amostra da memesfera "impeachment”. Segundo, e justamente pelas dificuldades técnicas acima mencionadas, trata-se de uma amostra de memes sobre o "impeachment" de Dilma Rousseff que não afirma ser representativa, já que me restrinjo a um corpus de memes que tive- 
ram tanta repercussão que foram reproduzidos para além de redes sociais como o Twitter, Facebook e Instagram, ou seja, na mídia de massa "tradicional" (versões on-line dos grandes jornais), em blogues especializados na coleção de memes, e em trabalhos acadêmicos. Em outras palavras, considerei os memes que conseguiram sair da efemeridade das mídias sociais e penetrar no arquivo da memória coletiva e do conhecimento institucionalizado. Obviamente, isto não pode garantir que o corpus abranja de fato os memes que mais foram repassados, recriados ou simplesmente curtidos. Terceiro, minha abordagem é restrita a memes que incluem imagens. Segundo Viktor Chagas et al. (2015, p. 17), estes representam a absoluta maioria dos memes e podem ser classificados em três grupos: primeiro, image macros, fotografias com legendas sobrepostas (ver fig. 1, "Já é impeachment na Austrália"); segundo, exploitables, fotomontagens que utilizam sobreposições (fig. 2, "Digam ao povo que eu fico!"); e terceiro, look-alikes, comparações em painéis duplos (fig. 3, "Separados por uma depilação a laser").

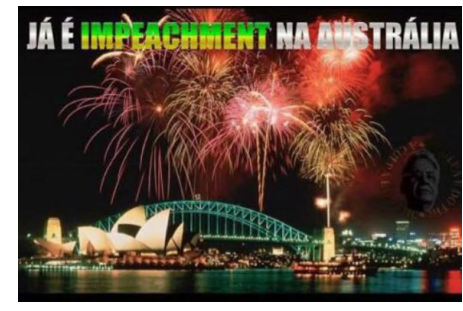

Fig. 1

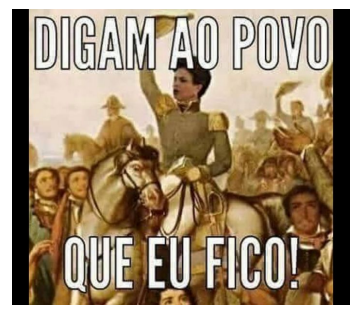

Fig. 2

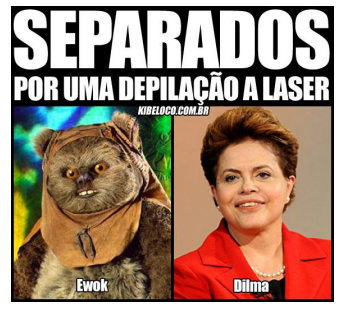

Fig. 3

A limitação do corpus a memes imagéticos corresponde à minha principal pergunta de investigação, que busca entender o uso do humor em memes sobre o "impeachment”, visando pessoalmente Dilma Rousseff, pela sua composição, linguagem e iconologia, em comparação à charge política, o formato mais tradicional e poderoso, que desde séculos vem cumprindo a função de comentar humoristicamente eventos políticos. Estão estes memes seguindo ou fortalecendo a tradição de crítica política pelo humor de tal forma que possam ser considerados uma nova expressão de cultura de empoderamento? Esta pergunta tem como premissa que seria possível examinar memes como uma nova expressão popularizada da já clássica charge política. É necessário frisar que a escolha desta abordagem abstrai de uma série de diferenças entre charge e meme, como a autoria amadora e múltipla e também a circulação, a presença instantânea e a mutação das imagens, além de não incluir as grandes questões relevantes para a compreensão integral do fenômeno da "memetização" acima discutidos. A razão é que estas questões, apesar de admitidamente pertinentes, são por ora metodicamente irrealizáveis. Consequentemente, meu enfoque me permite apenas examinar memes de internet como se fossem criações "originais" e "eternizadas". Entretanto, os memes que tiveram o sucesso de terem recebido a atenção da mídia tradicional de massa e que foram incluídos à memória midiática além da memesfera passam a ter justamente estas características, o que reduz o efeito de viés da metodologia ainda deficiente. 


\section{Meme e charge política}

Antes de tudo, a comparação do meme imagético com a charge política revela a similaridade de composição. Na verdade, o formato mais utilizado do image macro, a reprodução de uma imagem com legenda sobreposta, já existe na charge há muito tempo. O semanário humorístico Pasquim, fundado em junho 1969, ou seja imediatamente depois da proclamação do Ato Institucional $n^{\circ} 5$, apresenta, no número 72 , publicado no dia $1^{\circ}$ de novembro de 1970 , um caso paradigmático de uma charge política que compartilha com o meme imagético esta característica formal: é, como no caso da figura 2, uma reprodução da tela icônica "Independência ou Morte" de Pedro Américo (1888), com o acréscimo de um balão de fala que diz "Eu quero Mocotó", num arranjo tecnicamente pouco exigente (fig. 4). Apenas aparentemente inofensiva, a charge provocou uma reação furiosa pelo seu teor de crítica. No mesmo dia, praticamente todos os redatores foram presos pela polícia e mantidos durante dois meses. Este episódio significou praticamente o fim da revista, já que, além da prisão, o número 72 da revista foi confiscado e ela passou a ser censurada com o máximo de rigidez (WINK, 2004, p. 62). Oficialmente, as medidas drásticas foram justificadas pelo delito de desrespeito aos símbolos nacionais (WINK, 2002, p. 63). Mas, na verdade, o motivo foi completamente outro.

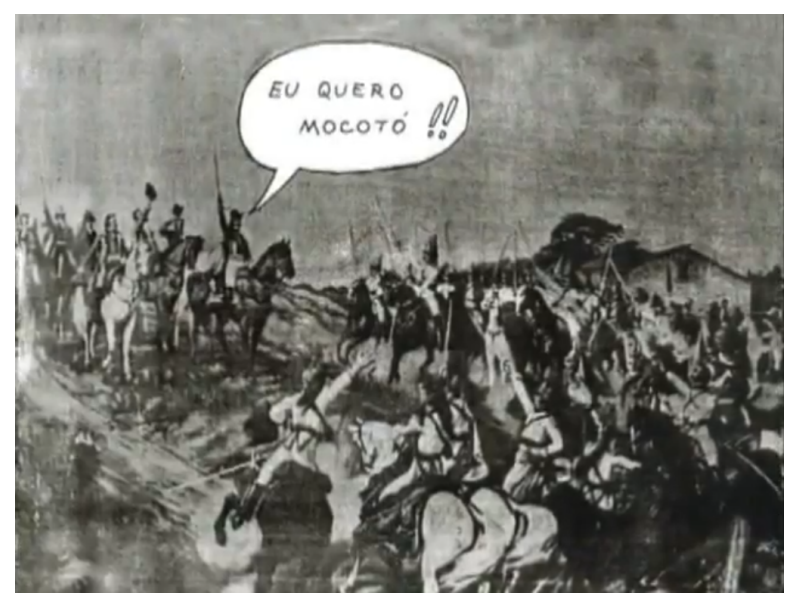

Fig. 4 - "Eu quero Mocotó!!”

A charge não se referia à tela de Pedro Américo, mas ao $5^{\circ}$ Festival Internacional da Canção, de 1970, no qual o cantor Erlon Chaves concorreu com a canção inédita de Jorge Ben Jor, intitulada "Eu quero Mocotó", e quase ganhou a competição. O problema foi que, em sua performance no palco, o afro-brasileiro Erlon Chaves se apresentou cercado por um grupo de mulheres loiras, dançando lascivamente em torno dele e, inclusive, beijando-o (o que não deixou de ter uma certa coerência, já que a palavra "mocotó" era, na época, também uma gíria para denominar a perna feminina). Pelo azar do cantor, o então presidente do regime militar, general Emílio Garrastazu Médici, tomou conhecimento do ocorrido (dizem as más lín- 
guas, que através da sua esposa escandalizada). Exigiu que precisava conter o "negro abusado" (DurANTE, 2014), que passou a ser acusado de assédio moral e obscenidade. Nesta perspectiva que leva em consideração o contexto, a composição da charge é genial: além de substituir o presidente do governo militar por um chefe de estado histórico, inverte os papéis entre a vítima e o opressor por atribuir a citação, motivo da repressão, ao próprio poder. Ainda por cima, expõe a hipocrisia do discurso oficial de um país sem racismo pela analogia a uma farsa política conhecida, já que o episódio do Grito do Ipiranga é considerado, pelos historiadores, um caso exemplar de construção de um mito fundacional (ver, por exemplo, Fitz, 2005; WINK, 2009). Vale observar que nem o racismo nem a opressão estão representados na charge, mas mesmo assim ela permite, ao observador atento, compreender a mensagem apenas aparentemente lúdica (e por isto foi censurada).

Entendendo o caso da charge "Eu quero Mocotó" como um padrão, qual seria sua relação com os memes imagéticos do corpus? A maioria destes memes recorre, de fato, no plano formal, a uma linguagem parecida de combinação de imagem e fala, embora com uma refinada elaboração técnica que se explica pela disponibilidade de ferramentas de processamento de imagem. Também quase todos têm em comum uma aparente pretensão de provocar um efeito risível (um caso algo malogrado é o meme "Vai fazer o que domingo companheira?", fig. 5). Declaradamente, a "zoeira", como dizem os internautas, é a força motriz dos memes. Pelo estado da arte, este humor das redes sociais se caracteriza pela ridicularização, pela comicidade da quebra de expectativas, por uma linguagem popular, permeada de repetitividade, e pela ênfase em situações fora do comum (Shifman, 2014). Portanto, é necessário considerar, para entender a função deste humor específico, as respectivas teorias básicas do humor (uma obra de referência é BERGER 1993, resumos úteis oferecem, por exemplo, PaUla; LoBo, 1997; Figueiredo, 2012).

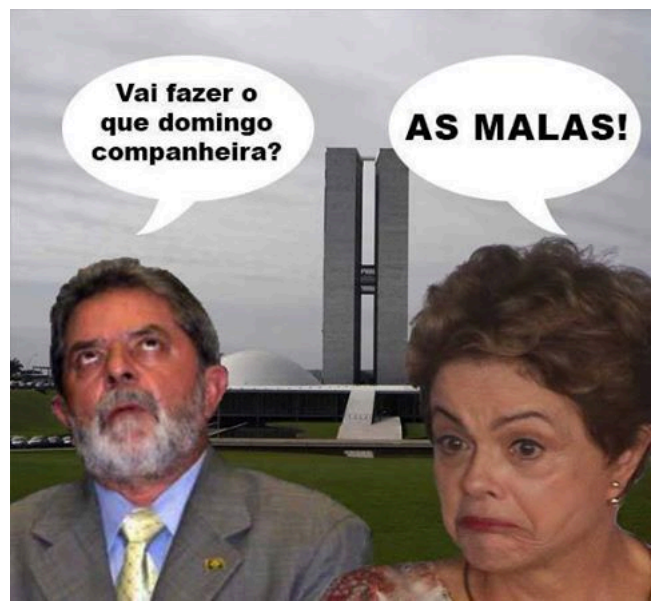

Fig. 5 


\section{Teorias do humor}

A mais antiga teoria do humor, que remete a Aristóteles e Cícero, é a teoria da superioridade. Segundo esta, o riso seria provocado pelas pessoas que apresentam algum defeito, que se encontram em posição de desvantagem ou sofrem algum pequeno acidente. A teoria foi referida na obra de Thomas Hobbes e desenvolvida proeminentemente por Henri Bergson no início do século XX. Resumidamente, propõe que o riso sobre o sofrimento do outro constitui, relativamente, um triunfo e enaltecimento próprio, a assim chamada glória repentina ou "sudden glory", nas palavras de Hobbes (1997, p. 46). Uma condição necessária para o ato se completar seria o abandono da empatia para com o outro, objeto da piada, e sua substituição pela indiferença (Bergson, 2012, p. 11). Por meio desta teoria é possível explicar, por exemplo, o meme "Dilma, a caza cail" (fig. 6). Uma vertente desta teoria trata o humor como fenômeno social que visa à construção de identidade coletiva de grupo pela inclusão e exclusão (o trabalho pioneiro é WolfF et al., 1934), como no exemplo do meme "Tá quase..." (fig. 7).

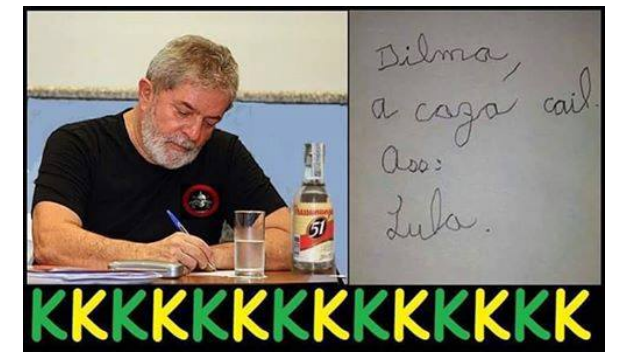

Fig. 6

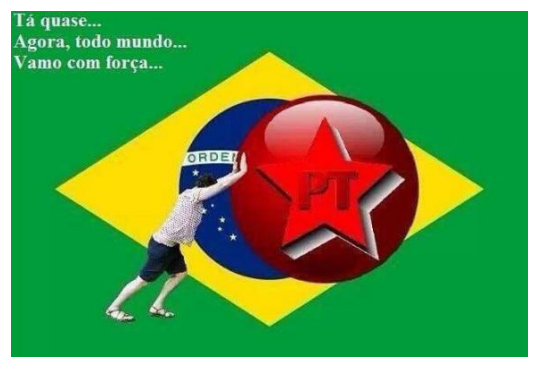

Fig. 7

A segunda abordagem, a teoria do alívio, frisa o aspecto emocional-fisiológico, explicando o humor como riso sobre a tragédia humana que permitiria reduzir a tensão psicológica. Tem a sua origem na psicanálise, segundo a qual o humor tem função terapêutica (a famosa "catarse"). Como Freud argumenta em Os chistes e a sua relação com o inconsciente (FREUD, 1905), o riso possibilita uma superação momentânea da barreira que nosso superego constrói. Ou seja, permite a vivência de desejos recalcados, como alívio e sem má consciência. Esta perspectiva psicanalítica também explica a forte presença de tabus no humor, tais como fornicação, defecação e outras funções gastrointestinais, ou seja, todo o complexo chamado de "carnavalesco". O meme "Foi horrível" (fig. 8) funciona por meio do humor terapêutico, porque projeta um trauma próprio para o caso do "impeachment", livrando-se, desta vez, do vexame, o que bem poderia render algum efeito catártico. Mesmo não sendo um meme (embora se possa discutir se, pela linguagem, forma de comunicação e divulgação não poderiam ser considerados memes não digitais), outro exemplo, ilustrativo para esta função do humor, sem que se façam necessárias maiores explicações, são os adesivos para carros (fig. 9), vendi- 
dos durante um tempo por $\mathrm{R} \$ 34$ e promovidos com a frase publicitária "adesive seu carro e se divirta protestando".

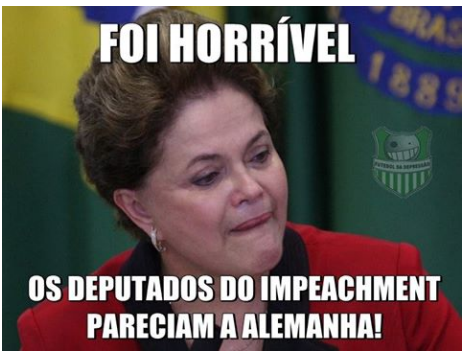

Fig. 8

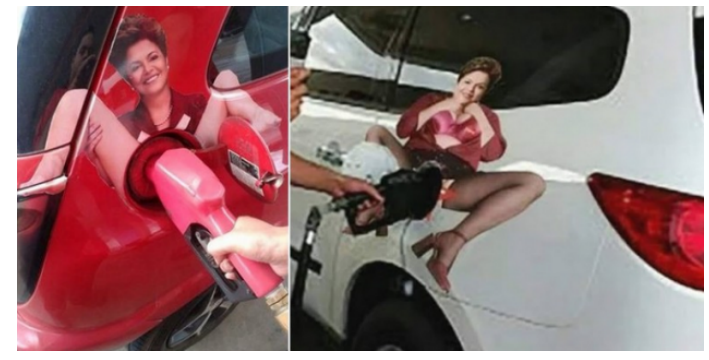

Fig. 9

Já a terceira perspectiva, pela teoria da incongruência, explica o riso pela mistura de ideias e situações disparatas, o que provoca uma expectativa frustrada, uma surpresa ou um paradoxo. Tem as suas raízes, entre outros, em James Beattie, quem em 1764 escreveu seu ensaio "On laughter and ludicrous composition" (BEATTIE, 2011), proporcionando os elementos básicos para uma abordagem linguística do humor, como realizado de forma prominente por Attardo e Raskin (2009) em sua General theory of verbal humor. Esta teoria permite tratar o humor em seu aspecto cognitivo, dependente do sistema de valores e da estrutura lógica da língua, por exemplo, em relação à polissemia, como em "Última notícia: Dilma acaba de sair de Brasília" (fig. 10), ou pela ironia hiperbólica em "Quem falou q a Dilma nunca fez nada de bom?" (fig. 11).

Vale ressaltar que, na aplicação, as teorias têm de ser usadas de forma suplementar, nunca isoladamente. Rimos do meme "Última notícia" porque Dilma fica apertada num carro popular, não pela polissemia algo forçada e manjada de "Brasília”. Seria então um riso por superioridade, atingida por meio da incongruência.

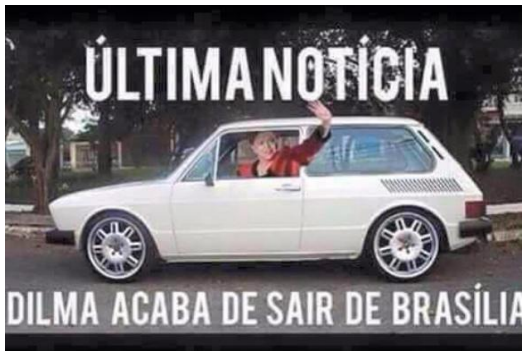

Fig. 10

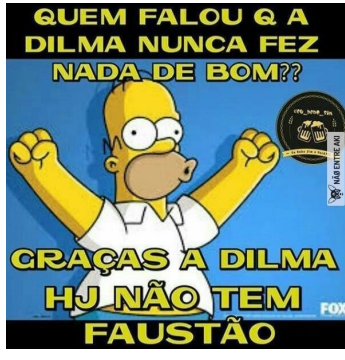

Fig. 11

\section{O humor presente nos memes sobre Dilma Rousseff durante o "im- peachment"}

Com base nessas teorias examinarei, em seguida, concisamente os restantes memes, ainda não apresentados, que constituem meu corpo de análise. Uma parte 
significativa tematiza o "impeachment", ou seja, o afastamento de um cargo eletivo, estabelecendo uma analogia com a situação de ser demitido de um emprego. O primeiro exemplo - "Bomba! Dilma acaba de divulgar que está grávida! Para não perder o emprego." (fig. 12) - ganha seu efeito risível não só pela sensação de superioridade em relação a uma pessoa que está em condições tão precárias que decide abusar da lei que regula o período de estabilidade provisória durante a gravidez, mas sobretudo veicula a agressão recalcada de ver Dilma Rousseff grávida, ressubmetida ao domínio masculino de fertilização, praticamente como se fosse o efeito das inúmeras penetrações imaginárias, efetuadas em postos de gasolina, mediante a imagem em adesivo e o bico de abastecimento.

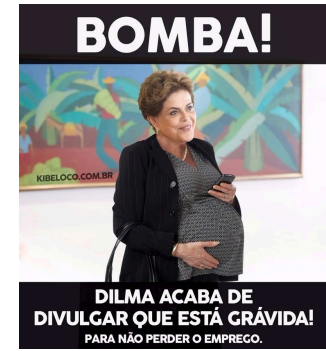

Fig. 12

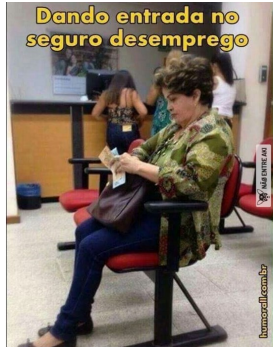

Fig. 13

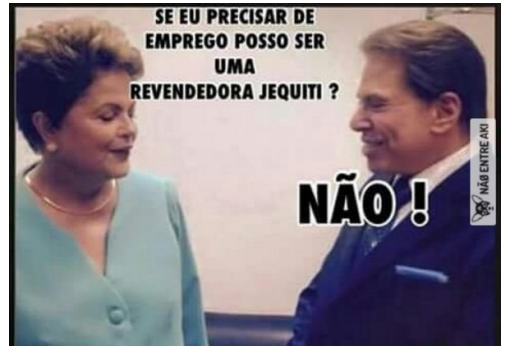

Fig. 14

O segundo exemplo, "Dando entrada no seguro desemprego" (fig. 13), se deleita com a ideia de que Dilma Rousseff, igual a qualquer outro desempregado, tenha que recorrer aos devidos seguros para sustentar a própria renda. Curiosamente, sugere ao mesmo tempo que ela não tenha conseguido acumular, durante o exercício do mandato, fortunas suficientes ou poder de traficar influência para poder prescindir do benefício ou pelo menos da presença pessoal no procedimento, o que poderia ser visto como uma distinção. Obviamente, o efeito tencionado aqui é pintá-la como mulher que precisa trabalhar, um estigma de classe social. Portanto, o efeito humorístico emana do sentimento de superioridade ou, mais precisamente, de vingança, porque é provável que a composição evoque associações masculinas em relação à situação de um divórcio que obriga a ex-esposa a se disponibilizar (mesmo que seja parcialmente) para o mercado de trabalho.

Outro exemplo, "Se eu precisar de emprego posso ser uma revendedora Jequiti?" (fig. 14), retoma a ideia e a especifica. O defeito risível de Dilma Rousseff não é só que ela tenha de trabalhar, mas que seja obrigada a trabalhar em profissões tidas como não qualificadas e com remuneração baixa, geralmente exercidas por mulheres, como a de revendedora de produtos cosméticos. ${ }^{2} \mathrm{O}$ fato, insinuado na resposta, de que Dilma Rousseff não esteja qualificada nem para esse tipo de emprego, provavelmente proporcione, no aprazedor do meme, um momento de glória até prolongado.

\footnotetext{
2 Este meme é o cúmulo de uma série de outros, com composição imagética parecida, que teve origem no perfil falso da Dilma Bolada e, apenas durante o processo de repassagem e adaptação, ganhou a conotação pejorativa.
} 
Tendo dado entrada no período de estabilidade provisória, seguro-desemprego ou com a primeira entrevista de emprego fracassada, sobra, como consolo, para a ex-presidente, a (duvidosa) oportunidade de aparecer no programa "Mais você" da apresentadora Ana Maria Braga, igual aos eliminados do programa televisivo "Big Brother Brasil" (fig. 15). Aqui o sentimento de superioridade é alimentado de outra fonte. A analogia do reality-show com a política, que não deixa de ser uma sugestão interessante, sugere que Dilma Rousseff tenha se candidatado ao mandato motivada por vaidade ou, no mínimo, carreirismo, o que novamente a coloca num lugar imaginário que reúne os estereótipos mais recorrentes sobre a mulher, tais como resumidos magistralmente por Michel Temer, seguidor de Dilma Rousseff no mandato, no discurso que pronunciou, em 8 de março de 2017, em homenagem ao Dia Internacional da Mulher. ${ }^{3}$ Além dos já mencionados, não pode faltar, é claro, o estereótipo mais antigo: a histeria feminina. Segundo o meme "Desculpa querida, não estou passando bem. Minha pressão caiu!” (fig. 16), o suposto distúrbio a torna inapta para arcar com responsabilidades hercúleas, tais como o mundo da política exige.

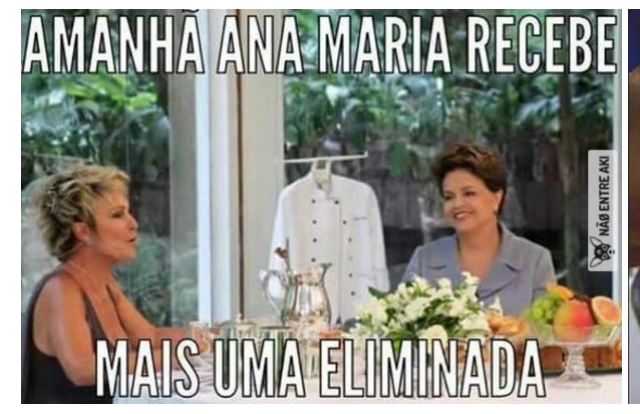

Fig. 15

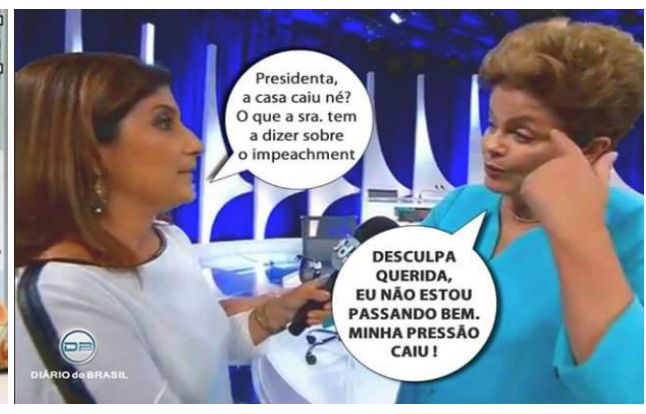

Fig. 16

É impressionante como a maioria dos memes utiliza rotineiramente como gancho, para veicular a sua crítica humorística à pessoa pública, o fato biológico de Dilma Rousseff ser uma mulher ("Dilma manipulando as massas", fig. 17), em vez de alertar a outras características possíveis, que, aliás, poderiam ser ainda mais inquietantes do que sua arte culinária, por exemplo sua suposta capacidade de doutrinação comunista. Stocker e Dalmaso (2016), que realizaram um mapeamento dos comentários ofensivos, direcionados a Dilma Rousseff no Facebook da Folha de S. Paulo, chegam à mesma conclusão: a maioria dos comentários contêm preconceito de gênero. Uma possível explicação, sob a hipótese de que muitos dos autores, (co)autores e divulgadores sejam masculinos, poderia ser uma relação profundamente e sistematicamente perturbada que este grupo social tem em relação ao sexo feminino. Aqui não é o lugar para indagar sobre as possíveis causas (e nem quero, com isto, sugerir que o problema seja apenas do Brasil). Sem dúvida, memes como "Oieeeeeeee...." (fig. 18), que outra vez faz referência a um episódio do "Big Brother Brasil", no qual uma candidata já eliminada surpreendentemente conseguiu voltar,

\footnotetext{
3 Disponível em: <https://goo.gl/4sr3ZG >. Acesso em: 20 out. 2017.
} 
sendo que o subtítulo "Passando só para lembrar que mamãe ama vocês!!!" revela mais sobre a intenção humorística, seriam objetos ricos de uma abordagem psicanalítica. Entretanto, seria insuficiente chamar esse distúrbio apenas de cultura do machismo, porque os exemplos mostram que o que está manifesto nos discursos dos memes é uma aversão patológica contra o sexo feminino, que inclui o sexismo e a pornografia, e portanto tem de ser chamado corretamente de misoginia.

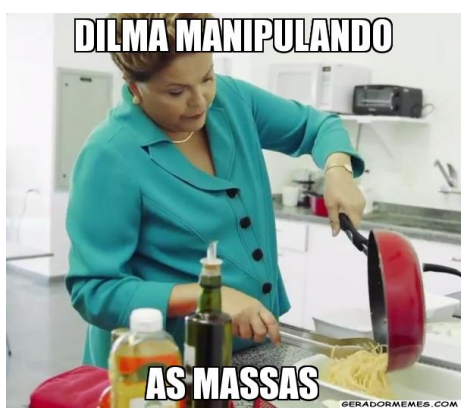

Fig. 17

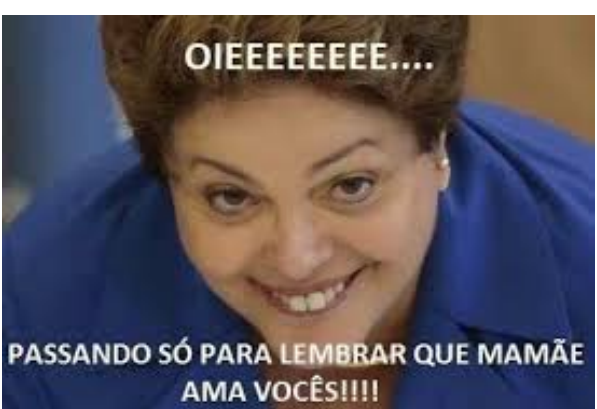

Fig. 18

Apenas pelos memes de internet que tematizam Dilma Rousseff durante o "impeachment", ficamos com a impressão de que o que mais inspira e instiga o humor (e ódio) dos internautas parece ter sido o simples fato de ela ter ocupado o cargo da presidência sendo mulher. Essa tendência contrasta com o tratamento dado a representantes masculinos em outros memes que focam políticos masculinos. Embora estes também costumem veicular uma difamação ad hominem, pelo ataque a questões pessoais, funcionam, por exemplo, pela infantilização ("Lembra quando eu te pedi um halls e a senhora disse que era o último???", fig. 19) ou se inspiram em hábitos de consumo de substâncias psicoativas ("Não vai sobrar nem o cheiro", fig. 20), mas nunca em supostos traços comportamentais ou de caráter relacionados ao papel de gênero.

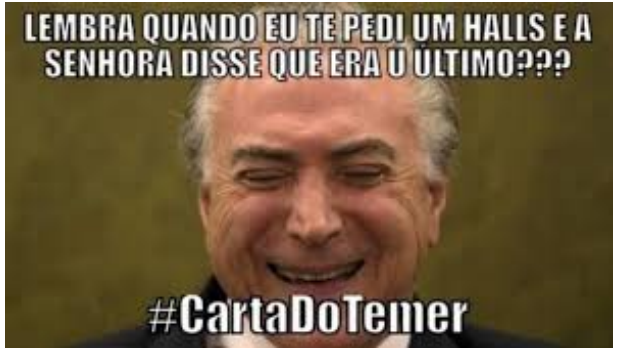

Fig. 19

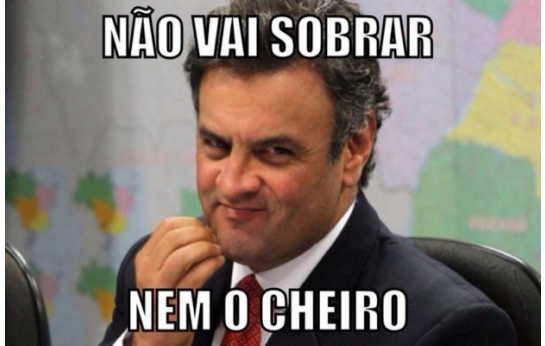

Fig. 20

\section{Conclusão}

Formalmente, podemos constatar, pela análise do corpus, uma preferência pelo exploitable e pelo image macro. Em relação à composição linguística e iconoló- 
gica, chama a atenção a reduzida complexidade. Sem ter aprofundado explicitamente esta observação, parece plausível que a principal razão não seja a limitação dos recursos técnicos (por isto fiz questão de apresentar, no início, a charge do Pasquim, que exemplifica que com recursos simples é possível criar uma enunciação requintada). O problema aparenta ser a futilidade da mensagem humorística. A análise do funcionamento do humor evidencia que, nos memes que tematizam Dilma Rousseff durante o processo do "impeachment", o riso é provocado (ou não), na maioria dos exemplos, pela sensação de uma superioridade relativa que, de maneira preferencial, alimenta-se pelo estímulo de agressões recalcadas. Os resultados indicam que estas agressões são motivadas pelo fato de a crítica humorística se referir a uma mulher, em posição supostamente incompatível com o seu gênero, mas sobretudo revelam a presença de um repertório convencional de estereótipos machistas e misóginos que é ativado em função do efeito humorístico. Em vista disto, a caracterização geral do humor dos memes de internet como "zoeira" teria de ser precisada, no que diz respeito aos memes que visam Dilma Rousseff no contexto do "impeachment", como a predominância de um sentimento de ódio sobre o humor, o que faria "escárnio" um termo mais adequado.

Muitas vezes já se saudou o argumento, especialmente relevante para contextos autocráticos, de que as mídias sociais teriam a capacidade de criar uma contranarrativa e até uma nova democracia participativa, um potencial de empoderamento, que Henry Jenkins (2004, p. 206) batizou de "photoshop for democracy". Indo além do escopo da pesquisa e arriscando uma perspectivação, o material estudado sugere que o contrário também é possível. O substrato dos memes analisados não é uma contranarrativa, mas a narrativa hegemônica, tal como imposta pela mídia tradicional de massa. Essa narrativa desfralda seu poder, pelo menos em parte, pelo estímulo de preconceitos atávicos (neste caso, contra mulheres). O fenômeno novo parece ser que alguns consumidores da mídia de massa, em vez de contradizerem esta narrativa hegemônica, adotam (ou afirmam) posturas conservadoras (ou radicais ou extremistas) e as condensam, com a facilidade dos meios técnicos, em forma de meme, que se dissemina, novamente com assustadora facilidade, pela rede, já que a maioria dos usuários das mídias sociais é manipulada pela mesma narrativa hegemônica. Ou seja, o assim chamado "midiota" (CostA, 2015) também está consumindo (e criando) conteúdos on-line, com o efeito, contrário ao esperado por Jenkins, de que a desinformação ainda seja fortalecida. Dessa forma, a abertura de novos canais de comunicação, sem que haja algum filtro para verificar a veracidade das informações, aparentemente contribui para a circulação de pós-fatos, já que estes são aceitos individualmente pela verossimilhança com a expectativa dos receptores. Quando repassados em massa, seu grau de circulação passa a legitimá-los como fatos (BENTES, 2016).

Se fosse apenas assim, correríamos o risco de os memes de internet servirem exclusivamente como catalisadores do mainstream da grande mídia e de os internautas, "ativistas de sofá" anonimizados, em vez de serem empoderados para manifestarem sua opinião independente, servirem como multiplicadores dessa opi- 
nião publicada. Entretanto, nem toda a mídia social é reacionária e nem todos os memes funcionam à base do escárnio. Portanto, julgo cabível encerrar a contribuição com uma exceção à regra: "Primeiro tira a Dilma... depois os outros" (fig. 21 e 22) é um meme em formato de GIF animado, o que obriga a incluir, neste caso, duas capturas numa sequência. É um meme, sem dúvida à altura das charges no Pasquim, que encontra uma metáfora clara para desvendar a tolice da crença, promovida pelos autores do "impeachment" e muitos outros, de que a luta contra a corrupção na política seria imparcial e exaustiva - e atingiria, logo ou depois, a todos os corruptos. Pelo momento, parece que a mensagem subliminar tem valor profético, já que a realidade tem-se mostrado oposta.

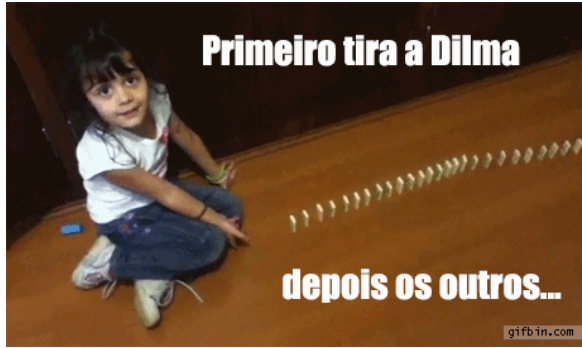

Fig. 21

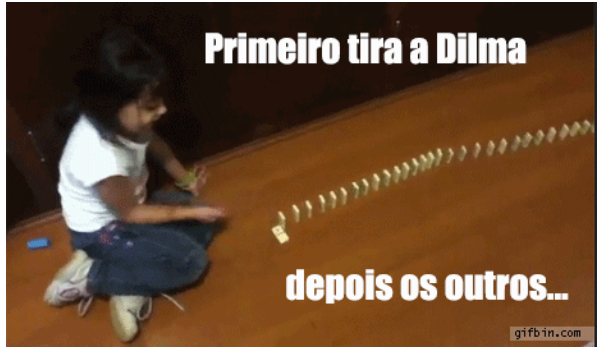

Fig. 22

\section{Referências}

AttARDo, Salvatore; RASKIn, Victor. Script theory revis(it)ed: joke similarity and joke representation model. Humor: International fournal of Humor Research, Berlin, v. 4, n. 3-4, p. 293-347, jan 1991.

BARREto, Krícia Helena. Os memes e as interações sociais na internet: uma interface entre práticas rituais e estudos de face. Tese (Doutorado em Linguística) - Universidade Federal de Juiz de Fora, Juiz de Fora, 2015.

Bauckhage, Christian. Insights into Internet Memes. Proceedings of the Fith International AAAI (Association for the Advancement of Artificial Intelligence) Conference on Weblogs and Social Media. Disponível em: <https://pdfs.semanticscholar. org/eaee/cfe9501e96b78b6c6fco73do822c9coc7b13.pdf>. Acesso em: 25 out. 2017.

BeATtie, James. Essays: On poetry and music, as they affect the mind; On laughter, and ludicrous composition. Charleston: Nabu Press, 2011.

Bentes, Ivana. A memética e a era da pós-verdade. Revista Cult, São Paulo, 31 out. 2016. Disponível em: <https://revistacult.uol.com.br/home/ a-memetica-e-a-era-da-pos-verdade>. Acesso em: 20 out. 2017.

Berger, Arthur Asa. An anatomy of humor. New Brunswick: Transactional Publishers, 1993. 
Bergson, Henri. Le rire: essai sur la signification du comique. Paris: Payot, [1900]2012.

Blackmore, Susan. The meme machine. Oxford: Oxford University Press, 1999.

BüLow, Christopher von. Mem. In: Mittelstraß, Jürgen (Org.). Enzyklopädie Philosophie und Wissenschaftstheorie. Stuttgart; Weimar: J. B. Metzler, 2013. v. 5. p. 31824 .

Castaño Díaz, Carlos Mauricio. Defining and characterizing the concept of Internet Meme. Revista CES Psicología, Medellín, v. 6, n. 2, p. 82-104, jan./jun. 2013.

ChaGAS, Viktor. "Não tenho nada a ver com isso": cultura política, humor e intertextualidade nos memes das Eleições 2014. In: Encontro ANUAL DA Associação Nacional dos Programas de Pós-Graduação em Comunicação, 15., Universidade Federal de Goiás, 7 a 10 jun. 2016. Anais... Goiânia: Compós, 2016 p. 1-24. Disponível em: <https://bit.ly/2MAtSjA>. Acesso em: 25 out. 2016.

Chagas, Viktor; Freire, Fernanda; Rios, Daniel; Magalhães, Dandara. A política dos memes e os memes da política: proposta metodológica de análise de conteúdo sobre memes dos debates nas Eleições 2014. In: Congresso DA Associação DE Pesquisadores em Comunicação e Política, 6., Pontifícia Universidade Católica do Rio de Janeiro, abr. 2015. Rio de Janeiro: Compolítica. 2015, p. 1-25. Disponível em: <https://bit.ly/2B4awC8>. Acesso em: 25 out 2017.

Costa, Luciano Martins. Breviário do perfeito midiota. Observatório da Imprensa, São Paulo, Programa n. 2.586, 16 abr. 2015. Disponível em: <https://bit.ly/1IPbrCH>. Acesso em: 30 ago. 2017.

DAwkins, Richard. The selfish gene. Oxford: Oxford University Press, 1976.

Durante, Flávia. O veneno de Erlon Chaves. Revista Trip, São Paulo, n. 231, 15 abr. 2014. Disponível em: <https://revistatrip.uol.com.br/trip/ o-veneno-de-erlon-chaves $>$. Acesso em: 20 ago. 2017.

Figueiredo, Celso. Por que rimos: um estudo do funcionamento do humor na publicidade. Comunicação e Sociedade, São Paulo, v. 33, n. 57, p. 171-198, jan./jun. 2012.

Fitz, Ricardo Arthur. Brasil: os mitos fundadores da nacionalidade. Ciências e Letras, Porto Alegre, n. 37, p. 9-24, jan./jun. 2005.

Freitas, Ana. Qual o papel dos memes na discussão política. Nexo fornal, São Paulo, 15 maio 2016. Disponível em: <http://www.nexojornal.com.br/expresso>. Acesso em: 26 mar 2018.

Freud, Sigmund. Der Witz und seine Beziehung zum Unbewussten: Der Humor. Frankfurt am Main: Fischer, 1992 [1905]. 
Hobbes, Thomas. Human Nature. London: Routledge; Thoemmes, [1839-1845]1997. (The Collected English Works 4).

Hofstede, Geert; Hofstede, Geert Jan; Minkov, Michael. Cultures and organizations: software of the mind. New York: McGraw-Hill, 2010.

Horta, Natália Botelho. O meme como linguagem da internet: uma perspectiva semiótica. Dissertação (Mestrado em Comunicação) - Universidade de Brasília, Brasília, 2015.

Jenkins, Henry. Convergence culture: where old and new media collide. New York and London: New York University Press, 2006.

Knobel, Michele; Lankshear, Colin. Online memes, affinities, and cultural production. In: Knobel, Michele; LAnkshear, Colin (Org.). A new literacies sampler. New York: Peter Lang, 2007. p. 199-227.

MALINI, Fábio. O método perspectivista de análise de redes sociais: cartografando topologias e temporalidades em rede. In: Encontro AnUal DA Associação NAcional dos Programas de Pós-Graduação em Comunicação, 25., Universidade Federal de Goiás, 7-10 junho 2016. Anais... Goiânia: Compós, 2016. Disponível em: $<$ http://www.labic.net/wp-content/uploads/2016/o6/compos_Malini_2016.pdf>. Acesso em: 26 mar. 2018.

Milner, Ryan. Pop polyvocality: internet memes, public participation, and the Occupy Wall Street Movement. International fournal of Communication, Los Angeles, n. 7, p. 2.357-2.39o, 2013.

MiLner, Ryan. The world made meme: discourse and identity in participatory media. Tese (Doutorado em Comunicação) - University of Kansas, Lawrence, 2012.

Paula, Suely Maria de; Lobo, Silva. Algumas considerações sobre uma teoria do humor. Scripta, Belo Horizonte, v. 1, n. 1, p. 150-162, jul./dez. 1997.

Penney, Joel. Motivations for participating in "viral politics": a qualitative case study of Twitter users and the 2012 US presidential election. Convergence: The International fournal of Research into New Media Technologies, v. 22, n. 1, p. 71-87, maio 2016.

Recuero, Raquel da Cunha. Memes e dinâmicas sociais em weblogs: informação, capital social e interação em redes sociais na Internet. Intexto, Porto Alegre, v. 2, n. 15, p. 1-16, jul./dez. 2006.

SEgEv, Elad et al. Families and networks of internet memes: the relationship between cohesiveness, uniqueness, and quiddity concreteness. fournal of Computer-Mediated Communication, Oxford, v. 20, n. 4, p. 417-433, mar. 2015.

Shifman, Limor. Memes in a digital culture. Cambridge: MIT, 2014 
SouzA, Tasso Gasparini de; Goveia, Fábio Gomes. Meme, Imagem e repetição: uma discussão acerca de alguns modelos para o estudo da mimese em imagens. In: Congresso Brasileiro de Ciências da Comunicação, 39., 4 a 7 set. 2016, São Paulo. Anais... São Paulo: Intercom, 2016. Disponível em: <http://portalintercom. org.br/anais/nacional2016/resumos/R11-1803-1.pdf>. Acesso em: 26 mar. 2018.

Stocker, Pâmela Caroline; Dalmaso, Silvana Copetti. Uma questão de gênero: ofensas de leitores à Dilma Rousseff no Facebook da Folha. Estudos Feministas, Florianópolis, v. 24, n. 3, p. 679-69o, set./dez. 2016.

TAY, Geniesa. Binders full of LOLitics: political humour, internet memes, and play in the 2012 US Presidential Election (and beyond). European fournal of Humour Research, v. 2, n. 4, p. 46-73, 2014.

Wiggins, Bradley E.; Bowers, Bret G. Memes as genre: a structurational analysis of the memescape. New Media \& Society, v. 17, n. 11, p. 1886-1906, 2014.

Wink, Georg. Alternative Presse in Brasilien (1964-82): Selbstverständnis und kultureller Ausdruck am Beispiel der humoristischen Zeitung "O Pasquim". Mettingen: Brasilienkunde-Verlag, 2002.

Wink, Georg. Die Idee von Brasilien: Eine kulturwissenschaftliche Untersuchung der Erzählung Brasiliens als vorgestellte Gemeinschaft im Kontrast zu Hispanoamerika. Frankfurt am Main: Peter Lang, 2009.

Wolff, H.A.; Smith, C. E.; Murray, H. A. The psychology of humor: a study of responses to race-disparagement jokes. Journal of Abnormal and Social Psychology, v. 28, p. 341-365, 1934 .

Recebido em 7 de novembro de 2017.

Aprovado em 13 de março de 2018.

\section{Resumo/Abstract/Resumen}

\section{Humor golpista: memes sobre Dilma Rousseff durante o "impeachment"}

\section{Georg Wink}

Este artigo tem como base um estudo exploratório e preliminar de caso sobre os memes imagéticos de internet que abordaram Dilma Rousseff na ocasião do "impeachment". O objetivo é compreender a sua função humorística, em recorrência a teorias básicas do humor. Parte-se da hipótese que os memes poderiam ser uma nova expressão popularizada da charge política. No entanto, esta abordagem encontra limites, porque o estado da arte ainda carece de um marco teórico contundente e de uma metodologia tecnicamente viável. A análise de uma amostra de memes, representativa pela sua recepção na mídia de massa, evidencia que o seu 
humor tem tendência para o escárnio, sugerindo superioridade relativa e estimulando agressões recalcadas. Conclui-se, que o principal alvo da crítica humorística desses memes não é a pessoa política, mas o gênero feminino da presidenta, lançando mão do repertório convencional de estereótipos machistas e misóginos.

Palavras-chave: memes de internet, imagem, Dilma Rousseff, impeachment, humor, gênero, misoginia.

\section{Putschist Humor: Memes addressing Dilma Rousseff during the "Impea- chment"}

Georg Wink

This article is based on an exploratory and preliminary case study about internet memes, which addressed Dilma Rousseff during the "impeachment". My objective is to understand them in terms of their functions of humor, drawing on basic theories of humor. My hypothesis is that memes could be a new popularized expression of the classical political cartoon. However, this approach encounters restrictions, as the state of the art still lacks convincing theoretical frameworks and a technically viable methodology. The analysis of a sample of memes, representative due to their reception in the mass media, shows a tendency towards ridicule and scorn by suggesting a relative superiority and stimulating repressed aggressions. The study concludes that the main goal pursued by these memes through humorous criticism is not the political person, but the female gender of the President, deploying the conventional repertoire of sexist and misogynist stereotypes.

Keywords: internet memes, image, Dilma Rousseff, impeachment, humor, gender, misogyny.

\section{Humor golpista: memes sobre Dilma Rousseff durante el "impeachment"}

\section{Georg Wink}

Este artículo tiene como base un estudio de caso exploratorio y preliminar sobre los memes de internet que abordaron a Dilma Rousseff con ocasión del "impeachment". El objetivo es entender su función humorística, en recurrencia a teorías básicas del humor. Se parte de la hipótesis de que los memes podrían ser una nueva expresión popularizada de la chargada gráfica política. Sin embargo, este enfoque encuentra límites, porque el estado del arte todavía carece de un marco teórico contundente y de una metodología técnicamente viables. El análisis de una muestra de memes, representativa por su recepción en los medios de comunicación de masas, evidencia que su humor tiende al escarnio, por sugerir una superioridad relativa y estimular agresiones reprimidas. Se concluye que el principal objetivo de la crítica humorística de los memes no es la persona política, sino el 
género femenino de la Presidenta, empleando el repertorio convencional de estereotipos machistas y misóginos.

Palabras clave: memes de internet, imagen, Dilma Rousseff, impeachment, humor, género, misoginia. 